\title{
Considerations about Flip Education in the Teaching of Advanced Mathematics
}

\author{
Cristina Jordán ${ }^{1, *}$, Ángel Alberto Magreñán ${ }^{2}$ and Lara Orcos ${ }^{3}$ \\ 1 Departament of Applied Mathematics, Universitat Politècnica de València, España, 46022 Valencia, Spain \\ 2 Departament of Mathematics and Computation. Universidad de La Rioja, 26002 Logroño, Spain \\ 3 Faculty of Education, International University of La Rioja, 26006 Logroño, Spain \\ * Correspondence: cjordan@mat.upv.es
}

Received: 30 June 2019; Accepted: 16 August 2019; Published: 28 August 2019

\begin{abstract}
The changes in our society in recent years and the consequent idiosyncrasy of young people demand new teaching methodologies. The methodology known as flip teaching, in which pupils study the subject before the class experience, using the material given by the teacher, makes it possible to turn the classroom into a place to solve different problems, to introduce new advanced concepts and to participate throughout collaborative learning in the classroom. Parallel to the social transformation, Information and Communication Technologies, also known as ICT, have undergone an important development accompanied by a clear reduction in costs and ease of use of different devices to create and edit quality videos, as well as the possibility of disseminating them on the network. In this way, the didactic material provided to the student can be in video format, which let us to be closer to students and also allow them to revise the class everywhere and all the times they need. In this work, we present and discuss the results of an experience carried out over several years with students of first and fourth grade of the subjects Discrete Mathematics and graphs, models and applications, respectively, at the Universitat Politècnica de València, in relation to the acceptance, advantages and drawbacks of flip teaching.
\end{abstract}

Keywords: Flip learning; ICT; Polimedia; video; collaborative work; advanced mathematics

\section{Introduction}

The changes that have led to the methodology known as flip teaching have their roots in the social transformations resulting from the stability and democratization of society, the development of new pedagogical lines and the exponential growth of technology. In relation to information and communication technologies, ICT, it is important to highlight that their development is accompanied by a clear reduction in costs and greater ease in the handling of different devices to create and edit quality videos, as well as to hang them almost automatically in the network.

However, it is crucial to bear in mind that for young people, among whom students are, this technological change has not taken place. Therefore, a change in our way of teaching is necessary to get closer to their way of learning and communicating.

In the university context, an effort of compression and analysis on the part of the students is essential. The students' attention is usually difficult to maintain since they get bored easily, probably due to the fact that they are used to obtain information quickly and immediately. They arrive at the university with a base and interests that are far from what we expect, at least as far as mathematics is concerned, so it is difficult to help them to develop reasoning and deduction skills. In many cases, they consider that the contents exposed by the teacher are clear, so they do not need to spend time to a further analysis [1]. Taking this into account, a change in the methodology is necessary so that students can occupy a more important position in the learning process. 
One of the challenges of a teacher is to ensure that the time shared with students in class is as fruitful as possible, making meaningful learning to be foster to allow future graduates to continue learning by themselves throughout their lives. Flip teaching is an evolution of the category of the teaching methods known as "peer instruction" [2] and "just-in-time teaching" [3], in which the basis is to obtain the maximum performance in the classroom, where the events that have traditionally taken place inside it, now are performed outside it [4], so the classroom becomes a place to carry out a more collaborative learning $[3,5,6]$. In this methodology, the didactic materials play a key role, so having a good and easy access to ICT will be of great help.

There are studies based on the application of this methodology in mathematics class with results and perceptions of the students. Thus, we can mention that, in relation to the final exams, the studies presented by Talbert [7], McGivney-Burelle and Fei Xue [8] and Love, Hodge, Grandgenett and Swift [9], show that students who have worked with flip methodology get similar marks in the exams to students who have followed a magistral methodology and, in relation to the videos, students think that their use is an effective way to learn new skills in mathematics. On the other hand, the results also show that they feel more comfortable when they use this methodology and that their perception of the usefulness of mathematics in their disciplines is greater than that of students in magistral classes.

The Universitat Politécnica de Valéncia (UPV) developed Polimedia in 2003, which is a system for recording High Definition (HD) videos of learning objects, using low-cost audio-visual studies [10], to be distributed offline through a learning management system, (Sakai). Within the program "Docencia en Red" (teaching in network), developed as technical support for the teachers to record Polimedia videos, some of them are an important part of an OpenCourseWare (OCW) [11] and two massive online open courses (MOOC), [12,13]. This online material is related to the subjects: Discrete mathematics (MAD) and graphs, models and applications (GMA), respectively, of first and fourth grades at the School of Higher Computer Engineering (ETSINF) of the UPV [14].

The commented videos, as well as those collected in https://bit.ly/2qVGWpQ have been the point of support for modifying our methodology towards flip teaching [15-20]. This is characterized, as we have said above, by exchanging the role of the student inside and outside the classroom. The most outstanding difference with magistral type methodologies is that, in this case, the student acquires the relevant information to be treated independently and prior to the classroom session, working with the materials proposed by the teacher. Consequently, the role of the teacher is also modified. In addition to the design of activities and teaching material, he also facilitates the teaching-learning process through the interaction with students in the classroom [21].

We do not mean that flip teaching is the panacea of teaching methods, therefore, it is necessary to take into account its drawbacks at the time of its application. Among these, we emphasize that success depends on the interest of the students more than in the case of magistral methodologies, so that if the number of students in the group is large, in addition to the difficulty entailed by this fact, the implementation of the new methodology can be more complicated. In addition, according to the requirements of the agenda, the use of this methodology may require more time, so sometimes it can involve an extraordinary effort for the students.

In relation to the student, the most common risk factors, according to our experience, that can influence in the success of the methodology are [22] as follows:

- $\quad$ Lack of daily habit of work.

- Reluctance to change methodology.

- Extracurricular activities in which the student spends a lot of time.

- Possible overlap of work with other subjects.

In order to analyze the opinion of the students of the subjects of MAD and GMA about flip education, we have proposed different on-line questionnaires using Google Docs [21-23] during the last eight years. We highlight a qualitative survey conducted in the fourth year of the grade of Computer Engineering [24]. We want to remark that since we have asked about different aspects of the subject, 
not only about flip teaching, and being that the profile of both subjects very different, the surveys of both courses did not have exactly the same questions.

In Section 2, we present how we implemented this methodology in our subjects, MAD and GMA, with the aim of achieving the objectives set, and expose the dynamics followed for the collection of data after the experience. In Section 3 we show the results obtained and, finally, in Section 4, we collect some ideas, as a conclusion, that may be useful at the time of implementing the methodology.

\section{Methodology}

The way of flip teaching methodology implementation in the classroom varies greatly from one subject to another and from one teacher to another. We present below the key points of our experience.

\subsection{Objectives}

The main objectives of our work are:

- To promote good habits of study of the students of MAD and GMA such as:

- $\quad$ To insist on the advantages of taking notes.

- $\quad$ To read carefully, underlining if necessary, the statements of problems.

- $\quad$ To value the importance of the development that leads to a solution.

- To facilitate a good and deeper understanding of the concepts to study. It is known that listening to something for the first time does not mean that it has been assimilated and that it can be remembered, although it had been perfectly understood. It is during the work of analysis, more than during the face-to-face session, when doubts or new questions may arise. On the other hand, if the student has to learn the concepts that will be worked in the classroom previously, he will be more receptive, the explanations provided by the teacher will be more useful and their questions will receive an immediate answer. In addition, immediate feedback from the teacher allows a deeper learning of the subject and helps to learn through practice, an aspect that is more difficult to obtain with a traditional methodology.

- To work on the improvement the coherent and intelligible expression of their ideas being able to defend them in a reasoning way. Verbal participation in class improves this competence.

- $\quad$ To encourage continued study as the only way to achieve meaningful learning.

- To facilitate the learning process. The student has to study the new content at home, a task that can be complicated or tedious, so the didactic materials provided should be very clear and attractive. In return, the gaps that may have arisen will be filled in the face-to-face class and, in the work at home after the class, he will not find great doubts about the content worked in the classroom, as often happens in traditional teaching.

- To improve motivation, as indicated by Bishop and Verleger in [25]. In general, the application of this methodology increases students' motivation to go to class. Due to the lack of training in scientific understanding, mathematical arguments are difficult to follow, which causes lack of interest in this area. The flip methodology, without investing so much time in the theoretical part, allows us to pay more attention to the aspects in which the students may have more difficulties and/or interest and influence positively on students' motivation.

- To achieve more participatory classes. Turning the classroom into a discussion space leads, naturally, to better a communication between teacher and students, and, as a consequence, allows the teacher to know the cognitive skills, the involvement and interest in the subject of their students better.

\subsection{Teacher's Activities}

The activities that the teacher has carried out in this experience are shown in Table 1. 
Table 1. Teacher's activities.

Activities to Be Done by Teachers

- To give information at the beginning of the course. The teacher has to encourage students through a stimulating face-to-face class in which and, in addition, explain the advantages of this methodology $[7,26,27]$.

- To provide a weekly tutorial. Good programming is essential for a successful implementation of this methodology, so the guide with the details of the work to be done has to be published weekly.

- To provide teaching materials. In our case, in addition to collections of problems, we have opted for Polimedia videos which are very clear, detailed and precise and have higher acceptance among young people than the written material. However, the use of videos can affect the benefits that reading scientific texts provides in relation to learning this type of language. Therefore, a formal language, both verbal and written, is necessary to be used and demand.

- $\quad$ To give importance to formative evaluation. As a part of the training process, the evaluation has to be continuous and parallel to the learning process. Therefore, the participation of the students in the classroom, the score obtained in the problems presented and in tests solved by Poliformat (Sakai platform) are taken into account. These activities are part of a formative evaluation in addition to the summative one. In the groups of MAD in first year, which are more numerous than those of GMA in fourth year, we also do an exam at the end of the semester. In the fourth year, this exam is replaced by the reading and presentation of a scientific work.

\subsection{Student's Activities}

The activities that students have to perform are shown in Table 2.

Table 2. Student's activities.

\begin{tabular}{l} 
Activities to Be Done by Students \\
\hline$-\quad \begin{array}{l}\text { Resolution of questions related to the material previously studied. The battery of questions that collect the } \\
\text { previous work of students as a review is focused to clarify those points that, by experience, are gaps or conflicting } \\
\text { points. We want to remark that this activity facilitates the habit of participating in the classroom. }\end{array}$ \\
Problem solving as part of the evaluation. The collection of problems proposed to be solved by students outside \\
the classroom in groups of two or three members are corrected and returned within a week. The goal is to \\
verbalize their ideas and to choose the best solution after a peer-to-peer discussion. This cooperation encourages \\
the acquisition of transversal skills such as the improvement in the use of scientific language and the ability to \\
work in groups [1]. \\
Solving reinforcement problems for the classroom. They are part of their individual work and involve fewer \\
difficulties than those of the previous item. They are solved at home and corrected in the classroom to reinforce \\
and complement the arguments that take place in the face-to-face session after watching the videos. \\
The reading and presentation of a scientific article. This is a proposal just for the students of GMA and consists of \\
making and presenting a poster that summarizes a scientific article.
\end{tabular}

\subsection{Sample}

- The collected data correspond, on the one hand, to a pilot group (Project flip classroom 2015) of flip education in the academic year 2017-2018 with 24 students who used the methodology $6 \mathrm{~h}$ per week during 15 weeks, to the double degree of Computer Science and Business Administration in the academic year 2016-2017 (both theory and practice) with 46 students who used methodology $4.5 \mathrm{~h}$ per week during 15 weeks, and to two practice groups of 45 students of the 2017-2018 academic year who used the methodology $1.5 \mathrm{~h}$ per week during 9 weeks, all of them from the first MAD subject (ETSINF). It is important to mention that the aforementioned students of the practice groups had teachers who followed a magistral methodology in theory classes.

- The rest of the data corresponds to the GMA subject (42 students) during the courses 2013-2014 to 2017-2018 who worked with methodology $4.5 \mathrm{~h}$ per week over the course of 10 weeks.

- The number of students enrolled in the GMA option is approximately 18 each year, so we have grouped their answers in a single table to compare them with the results corresponding to the MAD subject.

\subsection{Information Collection Tools}

The data has been collected through on-line questionnaires using Google Docs in which various items were evaluated on a Likert scale ( 1 to 5,1 being totally disagree and 5 totally agree). In the 
surveys there are always several open-ended questions, which, although they do not allow to obtain objective values of comparison, provide a very clear and global view of the students' opinions on the applied methodology.

\subsection{Data Analysis}

We have studied the descriptive statistics of the evaluations of the students of each item of the questionnaire and we have analyzed the correlations between some of them taking into account that we are working under nonparametric assumptions and that, therefore, the statistic that has been taken is the Spearman' Rho. The null hypothesis established is that there is no correlation at a significance level of 0.01 . In the case that the value obtained after the analysis of the correlations with the SPSS statistical package is less than 0.01 , the null hypothesis can be rejected and we can conclude that there is a significant correlation between the different items.

\section{Results and Discussion}

\subsection{Descriptive Analysis}

In Tables 3 and 4 and Figure 1 are part of the results of the questionnaires previously commented.

Table 3. Average results of the questionnaire of students of first course.

\begin{tabular}{|c|c|c|c|c|}
\hline Discrete Mathematics (MAD) & $\begin{array}{l}\text { Qualification } \\
\text { MAD Pilot }\end{array}$ & $\begin{array}{l}\text { Qualification MAD Comp. } \\
\text { Eng + BA }\end{array}$ & $\begin{array}{l}\text { Qualification } \\
\text { MAD Practices }\end{array}$ & $\begin{array}{c}\text { Maximum } \\
\text { Qualification }\end{array}$ \\
\hline $\begin{array}{l}\text { Average qualification of entrance } \\
\text { to University }\end{array}$ & 7.44 & 8.43 & 8.29 & 14 \\
\hline Average qualification in MAD & 5.47 & 6.74 & 6.33 & 10 \\
\hline $\begin{array}{l}\text { The flip methodology (watching } \\
\text { videos at home and using class time } \\
\text { to clarify, deepen, relate concepts, and } \\
\text { solve exercises) helped my learning }\end{array}$ & 4.13 & 3.56 & 3.71 & 5 \\
\hline $\begin{array}{l}\text { The teacher-student interaction } \\
\text { generated by the flip methodology } \\
\text { helped my learning }\end{array}$ & 3.88 & 3.44 & 3.17 & 5 \\
\hline $\begin{array}{l}\text { In general I liked the methodology } \\
\text { followed in class }\end{array}$ & 3.81 & 4 & 3.29 & 5 \\
\hline
\end{tabular}

Table 4. Average results of the questionnaire of students of fourth course.

\begin{tabular}{lcc}
\hline \multicolumn{1}{c}{ Graphs, Models and Applications (GMA) } & Qualification Obtained & Maximum Qualification \\
\hline Average qualification in GMA & 8.22 & 10 \\
\hline To know a priori the contents to work in class favors my learning & 4 & 5 \\
\hline $\begin{array}{l}\text { The flip methodology (watching videos at home and using class time to } \\
\text { larify, deepen, relate concepts and solve exercises) helped my learning }\end{array}$ & 4.18 & 5 \\
\hline $\begin{array}{l}\text { The workload of GMA subject is adequate } \\
\begin{array}{l}\text { The amount of non-contact work required by this subject is equivalent } \\
\text { to that required by a more magistral methodology }\end{array}\end{array}$ & 3.54 & 5 \\
\hline $\begin{array}{l}\text { The teacher-student interaction generated by the flip methodology } \\
\text { helped my learning }\end{array}$ & 4.80 & 5 \\
\hline I am satisfied with the quality of the subject & 4.62 & 5 \\
\hline
\end{tabular}

In light of the results obtained, we consider four new factors that influence the success of flip teaching:

- Number of hours of flip teaching. In the case of the students of MAD, those of the pilot and Computer Engineering and Business Administration groups, expended $3 \mathrm{~h}$ of theory per week for 15 weeks and $1.5 \mathrm{~h}$ of practices per week for 9 weeks. However, for students who only received instructions with this methodology in practices, the schedule was $5 \mathrm{~h}$ per week for 9 weeks. This is one of the reasons why the teacher-student interaction, as well as the adaptation time to the 
new methodology is much shorter in the second case. In addition, students consider the practices as secondary and estimate, erroneously, that the effort to be made must be less than in theory.

- University access mark. In relation to the level of the students when arriving the university, we emphasize that both the students of the double grade and those who only received flip teaching in practices, have the best access qualifications. The pilot group has a different profile, since it was formed at the explicit request of the students.

- Group size. The double grade group had the higher number of student, 46, which lead us to think that students appreciate this methodology better when the group is more reduced.

- Course. The students of the fourth grade chose the subject as an elective, which presupposes an interest in it.

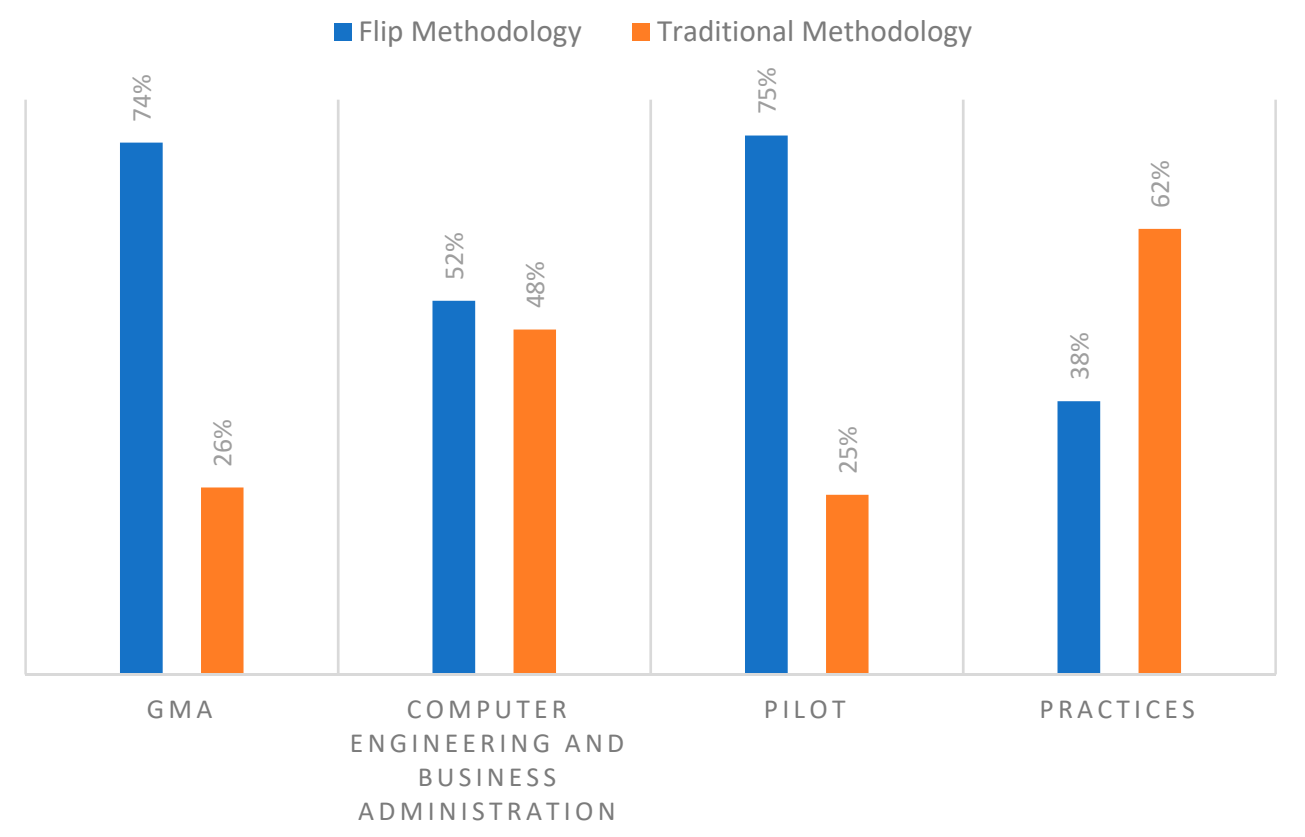

Figure 1. Results of the preference between flip and the magistral methodologies.

Taking into account the aforementioned factors, we analyze the data collected following two aspects:

- Comparison of students of MAD corresponding to the pilot and the double grade groups and the practices groups.

- $\quad$ The mark obtained in the subject depends on the access qualification to the UPV.

- In the question about whether flip teaching favors learning, the highest values are obtained by the pilot group, followed by the groups of practices. The fact that the score obtained in the double grade is a little lower than in the pilot group may be due to the number of students in the group, as it was practically double that in the other cases, as commented above. In the case of the group of practices, we believe that their opinions depend on the lower contact time with this methodology and their perception of the amount of effort that they should dedicate to the practices.

- $\quad$ Regarding the interaction with the teacher, the highest values were obtained again in the pilot group. However, the double grade group scores are higher than the in the practices group, which we believe is a consequence of the lower number of class hours received using this methodology. 
- $\quad$ About whether they liked the methodology, we observed a change in the data in relation to the pilot group and the double degree group. The score of the groups of practices in this case moves away from these values, possibly for the reason previously adduced.

- Comparison of the MAD flip pilot group and the double group with the GMA fourth group.

- In the questions referring to whether the methodology and the interaction with the teacher favor learning, the students of GMA scored higher than the ones of MAD. We could find an explanation based on the level of maturity of the students.

\subsection{Correlation Analysis}

We have observed the correlations between the different items shown in Table 5 throughout the Spearman's Rho statistic according to the preference or not for the flip methodology in the students of MAD.

Table 5. Correlations between the items among MAD students (Spearman's, ${ }^{* *}$ significant correlation at 0.01 level, C.C. means correlation coefficient and Sig. means signification, Trad. alludes to students rather than traditional methodology).

\begin{tabular}{|c|c|c|c|c|c|c|c|c|c|c|}
\hline & \multicolumn{2}{|c|}{ MAD Qualification } & \multicolumn{2}{|c|}{ Environment } & \multicolumn{2}{|c|}{ Like } & \multicolumn{2}{|c|}{ Videos at Home } & \multicolumn{2}{|c|}{ Exam Preparation } \\
\hline & C.C. & Sig. & C.C. & Sig. & C.C. & Sig. & C.C. & Sig. & C.C. & Sig. \\
\hline Difficulty MAD Flip & $-0.525 * *$ & 0.004 & -0.045 & 0.819 & -0.168 & 0.392 & -0.235 & 0.229 & -0.375 * & 0.049 \\
\hline Difficulty MAD Trad. & -0.427 & 0.113 & -0.205 & 0.463 & -0.253 & 0.362 & -0.353 & 0.196 & $-0.552 *$ & 0.033 \\
\hline Effort Trad & $0.765 * *$ & 0.001 & 0.401 & 0.139 & $0.540 *$ & 0.038 & 0.203 & 0.467 & $0.572 *$ & 0.026 \\
\hline Exercises Flip & $0.562 * *$ & 0.002 & $0.421 *$ & 0.026 & $0.623 * *$ & 0.000 & 0.176 & 0.370 & 0.195 & 0.32 \\
\hline Exercises Trad. & 0.224 & 0.423 & 0.440 & 0.100 & 0.285 & 0.303 & 0.374 & 0.170 & 0.183 & 0.515 \\
\hline Environment Flip & 0.119 & 0.545 & 1.00 & 0.000 & $0.534 * *$ & 0.003 & 0.125 & 0.527 & 0.111 & 0.576 \\
\hline Environment Trad. & 0.284 & 0.306 & 1.000 & 0.000 & $0.605 *$ & 0.017 & 0.065 & 0.819 & 0.131 & 0.643 \\
\hline Like Flip & $0.574 * *$ & 0.001 & $0.534 * *$ & 0.003 & 1.000 & 0.00 & 0.201 & 0.306 & 0.451 * & 0.016 \\
\hline Like Trad. & 0.624 * & 0.013 & 0.605 * & 0.017 & 1.000 & 0.00 & -0.295 & 0.285 & -0.057 & 0.839 \\
\hline Interaction T-S Flip & -0.015 & 0.938 & 0.205 & 0.297 & 0.332 & 0.084 & $0.776 * *$ & 0.001 & $0.764^{* *}$ & 0.000 \\
\hline Interaction T-S Trad. & 0.196 & 0.485 & -0.077 & 0.784 & -0.003 & 0.991 & 0.165 & 0.400 & $0.619^{*}$ & 0.014 \\
\hline Exam Preparation Flip & 0.243 & 0.213 & 0.111 & 0.576 & $0.451 *$ & 0.016 & 0.686 ** & 0.005 & 1.000 & 0.000 \\
\hline
\end{tabular}

- $\quad$ Among the students who prefer flip teaching:

- $\quad$ There is negative significant correlation of -0.525 , between the qualification obtained with the difficulty they consider the subject implies. If the subject seems difficult for them, it is more difficult to study and consequently they get lower marks. This relation is not appreciated among those who prefer a magistral methodology.

- $\quad$ There is also a positive correlation, 0.562 , between the fact that exercises and tasks have helped them in the learning of the subject and the qualification, that means that the more useful the exercises are, the better are the marks obtained. This situation is not the same among students who opted for a magistral methodology.

- There is also a significant correlation of 0.574 between the qualification and the fact that they like the methodology. We can deduce that if they enjoy learning while they get better grades.

- $\quad$ The effort is related to the work environment and the taste for the methodology $(0.564$ and 0.559 respectively), which means that the better the working environment and the more they enjoy it, the harder they work This significant correlation is not seen in the group that prefers the magistral methodology.

- $\quad$ The taste for the MAD subject is related to consider that the exercises and tasks, the rhythm of the class and the environment are adequate $(0.623,0.544$ and 0.534 respectively).

- Watching videos at home improves the interaction with the teacher (0.776) and makes they feel better prepared for the exam (0.686). 
- A greater interaction with the teacher also leads them to be better prepared for the exam (0.764).

- Among students who prefer the magistral methodology there are fewer significant correlations:

- $\quad$ Regarding the correlation between the qualification obtained with the effort made throughout the course, a coefficient of 0.765 is obtained in the group that would opt for magistral teaching.

- $\quad$ The rhythm in the classroom is related to the good environment (0.739).

Both the difficulty of the subject and the usefulness of the exercises are more perceived when flip teaching is used rather than in the magistral method, since it involves a continuous work that allows students to be more aware of both aspects. Moreover, for students who prefer the magistral methodology, daily work requires a lot of effort, while those who have chosen flip teaching have adapted to study daily, to invest a certain amount of time each week in the subject, and that adaptation makes them consider that the necessary effort is less.

We can conclude that the flip methodology favors collaborative learning environments and the results of the third item are also very positive, as it follows that the flip methodology makes the teacher-student interaction better, an aspect that influences their preparation for the exam.

\section{Conclusions}

Flip teaching is presented as an adequate option to improve the teaching-learning process of students in today's society. The exposed results, related to the different experiences made in the class and the subsequent analysis of the results obtained in the questionnaires, have given us a clear idea of the advantages and disadvantages that this methodology presents.

In relation to the stated objectives, we point out that they are have been reached according to the level of involvement of the student in the process. The method mainly benefits the liable students who attend class and are guided by the teacher.

It is also important to mention that it can be difficult to expect students to watch the videos before the class session if they do not feel pressured. An opinion shared by most of the students of all these years, is that it involves a continuous work, the workload being very large, but that allows the student to obtain better results. Therefore, in some courses, students have to answer to a simple test before each face-to-face session (held on the Poliformat platform). This fact is considered crucial for the correct implementation of the methodology because all students have to participate in the development of the class. In this line, knowing the names, or nicknames, of our students and using them whenever we have the opportunity, means a big change in the classroom environment. This also leads to more dynamism in the classes where students really appreciate the interaction with the teacher.

Regarding the teaching organization, it is convenient, although not always possible, that the face-to-face classes are not on correlative days, since this interferes with the completion of work at home. Moreover, much of the success of the methodology lies, in our case, on the good weekly program of the course and on the Polimedia videos, whose use is unanimously recognized by the students, as well as in the question-answer format used and the climate generated in class.

Flip teaching has some disadvantages that can be difficult in terms of a successful implementation, depending on the level of the group and the number of students, but we believe that it is an experience that is worth pursuing, despite the work involved, because the results can be very satisfactory. However, if the teacher does not get the group involved, it will be necessary to adapt the methodology to problems raised. What seems unquestionable for us is that it promotes a more meaningful learning experience, in which the learning process of the student will be much more fruitful, comfortable and lasting.

Author Contributions: All authors have contributed equally. 
Funding: The research was supported in part by Programa de Apoyo a la investigación de la Fundación Séneca-Agencia de Ciencia y Tecnología de la Región de Murcia [grant number 20928/PI/18 and by Spanish Ministerio de Ciencia e Innovación (MCINN) [grant number PGC2018-095896-B-C21].

Conflicts of Interest: The authors declare no conflicts of interest.

\section{References}

1. Jordán, C.; Cordero, A.; Torregrosa, J.R. How do current students face math problems solving? In Proceedings of the 9th International Technology, Education and development Conference, Madrid, España, 4 March 2015; pp. 4716-4721, ISBN 978-84-606-5763-7.

2. Crouch, C.H.; Mazur, E. Peer instruction: Ten years of experience and results. Am. J. Phys. 2001, 69, 970-977. [CrossRef]

3. Novak, G.M.; Gavrin, A.; Wolfgang, C.Y.; Patterson, E. Just-in-time teaching: Blending Active Learning with Web Technology; Prentice Hall PTR: Hoboken, NJ, USA, 1999.

4. Lage, M.J.; Platt, G.J.; Treglia, M. Inverting the classroom: A gateway to creating an inclusive learning environment. J. Econ. Educ. 2000, 31, 30-43. [CrossRef]

5. Bergmann, J.; Sams, A. Flip Your Classroom: Talk to Every Student in Every Class Every Day; International Society for Technology in Education: Washington, DC, USA, 2012.

6. PROYECTO CLASE INVERSA. Universitat Politécnica de Valencia, 2017. Sakai Project. Available online: https://bit.ly/2zFYN9Z (accessed on 29 October 2018).

7. Talbert, R. Inverted classroom. Colleagues 2012, 9. Available online: https://bit.ly/2E7udd0 (accessed on 22 November 2018).

8. McGivney-Burelle, J.; Xue, F. Flipping Calculus. PRIMUS 2013, 23, 477-486. [CrossRef]

9. Love, B.; Hodge, A.; Grandgenett, N.; Swift, A.W. Student learning and perceptions in a flipped linear algebra course. Int. J. Math. Educ. Sci. Technol. 2014, 45, 317-324. [CrossRef]

10. Turró, C.; Cañero, A.; Busquets, J. Video Learning Objects Creation with Polimedia. In Proceedings of the IEEE International Symposium on Multimedia, Washington, DC, USA, 13-15 December 2010; pp. 371-376. [CrossRef]

11. Jordán, C. Materiales docentes de la asignatura Estructuras Matemáticas para la Informática II. 2010. Available online: https://bit.ly/2hEHHS7 (accessed on 15 May 2018).

12. Jordán, C.; Conejero, A. Aplicaciones de la Teoría de grafos a la vida real (I) 2015a. Class Notes. Available online: https://bit.ly/1PeOrk3 (accessed on 16 February 2019).

13. Jordán, C.; Conejero, A. Aplicaciones de la Teoría de grafos a la vida real (II) 2015b. Class Notes. Available online: https://bit.ly/2ravmYV (accessed on 12 February 2019).

14. Cordero, A.; Jordán, C.; Sanabria, E.; Torregrosa, J.R. Towards a better learning model through OCWs and MOOCs. Int. J. Artif. Intell. Interact. Multimed. 2015, 3, 26-30. [CrossRef]

15. Jordán, C. Utilización Correcta e Incorrecta de Los Ficheros Polimedia. In Proceedings of the JIDINF'09, Valencia, Spain, 1 October 2009; ISBN 978-84-8363-464-6.

16. Jordán, C. Evaluación continua en la asignatura Estructuras Matemáticas para la Informática II. In Proceedings of the IX. Jornadas de Redes de Investigación en Docencia Universitaria, Alicante, España, 17 June 2011; ISBN 978-84-694-9813-2.

17. Jordán, C.; Alcover, R.M.; Conejero, J.A.; Cordero, A.; Pérez, M.J.; Sanabria, E.; Torregrosa, J.R.; Vázquez, E. Influencia de la educación inversa en el aprendizaje y adquisición de competencias transversales. In Congreso Nacional de Innovación Educativa y de Docencia en Red; Editorial UPV: Valencia, Spain, 2015. [CrossRef]

18. Jordán, C.; Torregrosa, J.R. Docencia en red: Un paso adelante en el uso de nuevas tecnologías. In $L a$ Formación y las Nuevas Tecnologias en la Docencia Universitaria; Membiela, P., Casado, N., Cebreiros, M.I., Eds.; Edición Editora: Alicante, España, 2008; pp. 726-735. ISBN 978-84-15524-09-0.

19. Jordán, C.; Torregrosa, J.R. Los objetos de aprendizaje y el nuevo contexto educativo (2008b). In Proceedings of the $V$ Congreso Iberoamericano de Docencia Universitaria, Valencia; Editorial: Universidad Politécnica de: Valencia, Spain, 2009; ISBN 978-84-8363-413-4.

20. Jordán, C.; Torregrosa, J.R. Las OCW en el nuevo contexto educativo. In Proceedings of the VIII Jornadas de Redes de Investigación en Docencia Universitaria, Alicante, España, 9 July 2010; pp. 2344-2357, ISBN 978-84-693-6845-9. 
21. Jordán, C.; Pérez, M.J.; Sanabria, E. Investigación del impacto en un aula de matemáticas al utilizar flip education. Pensam. Matemático 2014, 4, 9-22.

22. Jordán, C.; Pérez, M.J.; Sanabria, E. Flipped Clasroom: Reflexiones y Opiniones de los Implicados. In Proceedings of the Jornadas de Innovación Educativa y docencia en Red de la Universitat Politècnica de València, Valencia, Spain, 15-16 July 2014; Editorial UPV: Valencia, Spain, 2014; pp. 310-323. Available online: http://hdl.handle.net/10251/66232 (accessed on 16 February 2019).

23. Alcover, R.M.; Jordán, C.; Sanabria, E.; Vázquez, E. Qué opinan de la metodología flip teaching los alumnos de nuevo ingreso? CUIEET XXIII; 2015; pp. 1169-1182, ISBN 978-84-606-5611-1.

24. Jordán, C.; Pérez, M.J.; Sanabria, E. Educación inversa, una metodología innovadora ¿Coincide la percepción que tienen los alumnos de ella con la nuestra? In Proceedings of the de las XIII Jornadas de Redes de Investigación en Docencia Universitaria, Alicante, España, 3 July 2015; pp. 1967-1977, ISBN 978-84-606-8636-1.

25. Bishop, J.; Verleger, M.A. The Flipped Classroom: A Survey of the Research. Paper presented at 2013 ASEE Annual Conference \& Exposition, Atlanta, GA, USA, 23-26 June 2013; Available online: https://bit.ly/2rkhNGt (accessed on 12 February 2019).

26. Miller, A. Five best practices for the flipped classroom. Edutopia 2012, 24, 2-12.

27. Tucker, B. The flipped classroom. Educ. Next 2012, 12, 82-83.

(C) 2019 by the authors. Licensee MDPI, Basel, Switzerland. This article is an open access article distributed under the terms and conditions of the Creative Commons Attribution (CC BY) license (http://creativecommons.org/licenses/by/4.0/). 